Reprod. Nutr. Dévelop., 1987, 27 (2 B), 571-579.

\title{
Insulin-like growth factor (IGF) binding in hypophysectomized rat liver microsomes : alteration by a soluble binding moiety
}

\author{
B. BARENTON (1), Barbara A. PATEL $\left({ }^{*}\right)$, Monique M. BLANCHARD, \\ H. J. GUYDA $\left({ }^{*}\right)$, B. I. POSNER $(*)$
}

Station de Physiologie Animale, I.N.R.A., Montpellier, France.

(*) Departments of Pediatrics and Medicine, Mc Gill University, Montreal, Canada.

\begin{abstract}
Summary. In this study, we compared the binding of IGF-I and IGF-II to liver microsomes of normal and hypophysectomized (Hypox) rats. The binding of [125I]-|GF-II, measured by centrifugation of membrane-bound ligand, was lower in Hypox than in normal rats $(15 \pm 2$ vs $26 \pm 1 \%, p<0.001)$ but binding was increased $(46 \pm 1.5$ vs $31 \pm 1 \%$, $p<0.001)$ when bound and free hormones were separated using polyethyleneglycol (PEG) precipitation. This was due to the presence of soluble binding activity which dissociated from membranes to compete for IGF binding. When soluble binding activity was first removed from microsomal membranes by a washing procedure no difference was found in [25I]-IGF-II binding to microsomes of Hypox and normal animals $(33 \pm 1$ vs $32 \pm 1 \%)$. However, in the microsomal washing supernatant from Hypox (containing soluble binding activity) IGF-II binding was much higher than in that from normals (17 \pm 2 vs $6 \pm 0.5 \%$, $p<0.001)$. The binding of $\left[{ }^{125} \mid\right]-\mid$ GF-I was lower than that of $\left[{ }^{125} \mid\right]-I G F-11$ but was comparably changed. By contrast, $\left[{ }^{125} \mathrm{I}\right]$-insulin binding was similar in Hypox and normal rats and was not influenced by PEG precipitation or prewashing of the membranes.

Inhibition dose-response curves showed a paradoxical increase in [125|]-IGF-II binding to unwashed microsomes of Hypox rats in the range of $0.5-5 \mathrm{ng} / \mathrm{ml}$ cold IGF-II. In normal animals [ ${ }^{125}$ I]-IGF-II binding to microsomes was progressively inhibited by IGF-II in a range of $0.5-500 \mathrm{ng} / \mathrm{ml}$. For soluble binding sites, assayed by PEG precipitation, there was a dose-dependent inhibition of $\left[{ }^{125} \mid\right]-I G F-I I$ binding. The $I_{50}$ for the soluble binding moiety in Hypox $(3.5 \mathrm{ng} / \mathrm{ml})$ was almost half that found for microsomal receptors $(6 \mathrm{ng} / \mathrm{ml})$.

We conclude that hypophysectomy does not affect IGF binding to rat liver microsome receptors, but is associated with the accumulation of a high affinity binding activity which dissociates from the membranes in Hypox animals.
\end{abstract}

\section{Introduction.}

Insulin-like growth factors (IGFs) are polypeptides that have been proposed as the mediators of the peripheral actions of growth hormone $(\mathrm{GH})$. Two major IGFs have been characterized in human plasma : IGF-I whose secretion is mainly under the control of GH, and IGF-II whose GH-dependency is less clear (Zapf et al., 1981 ; Daughaday et al., 1981b ; Roberts et al., 1986).

(1) To whom correspondence should be addressed : I.N.R.A.-E.N.S.A., Station de Physiologie Animale, 9, place P.-Viala, 34060 Montpellier Cedex, France. 
Unique among polypeptide hormones, IGFs circulate in blood largely complexed to binding proteins of higher molecular weight (Moses et al., 1976 ; Hintz et al., 1981 ; Binoux et al., 1982a, b). IGF binding proteins are a family of heterogeneous peptides which also differ with respect to their $\mathrm{GH}$-dependency (Rechler et al., 1980 ; Furlanetto, 1980 ; Morris and Schalch, 1982). These proteins are often described as simple carrier proteins appearing to prolong the half-life of IGFs (Cohen and Nissley, 1976) and to prevent diffusion out of the capillary bed (Moses et al., 1976). More recent reports suggest that binding proteins modulate IGF biological effects (Drop et al., 1979) in inhibiting IGF binding to cell membrane receptors either by competition with IGFs or by altering binding directly at the cell surface (De Vroede et al., 1986 ; Clemmons et al., 1986).

IGFs bind to two different but specific membrane receptors in target tissues (Kasuga et al., 1981 ; Nissley and Rechler, 1985). Rat tissues possess mainly type-II IGF receptors (Daughaday et al., 1981a ; Nissley and Rechler, 1985). The following experiments were designed to study the effects of hypophysectomy and therefore $\mathrm{GH}$ status on IGF binding to rat liver microsomes. No effect was observed on plasma membrane receptors, but the binding of |GF-I and IGF-II was altered by a tissue binding protein moiety resembling one species of IGF binding protein. This binding protein was increased in hypophysectomized animals compared to normal control.

\section{Materials and methods.}

Animals. - Normal and hypophysectomized (Hypox) male Sprague-Dawley rats were obtained from Charles River Canada Inc (St Constant, Quebec) and maintained on Purina Chow. Hypox rats were operated upon when they were 27days-old and then received water containing $5 \%$ sucrose. Hypophysectomy was confirmed by observing the growth rate over a two-week period. All rats were fasted overnight before being sacrificed.

Hormones and other chemicals. - IGF-I and IGF-II were isolated by HPLC from a semi-pure preparation (IGFs) obtained by acid gel filtration of acid-ethanol extracts of Cohn fraction IV-4 of human plasma (Posner et al., 1978, Blanchard et al., 1987). Porcine insulin $(24.5 \mathrm{U} / \mathrm{mg})$ was a gift from Connaught Laboratories (Willowdale, Ontario). Carrier-free [125I]-iodine was purchased from NEN Corp (Boston, MA). Bovine serum albumin (BSA) was obtained from Sigma (St Louis, MO), rabbit gammaglobulin from Daymar Laboratories (Toronto, Ontario) and Sephadex G-50 from Pharmacia Fine Chemicals (Uppsala, Sweden). All other chemicals were analytic grade.

[125I]-labelling of IGF-I, IGF-II and insulin was performed by the chloramine-T method followed by purification by Sephadex G-50 chromatography (IGF-I and insulin) or binding to and elution from purified human placental microsomes (IGFII), as previously described by Posner et al. (1978). 
Microsome preparation. - Rats were anesthetized with ether. The blood was removed by circulating saline solution $(0.9 \% \mathrm{NaCl})$ in situ through the portal vein for $10 \mathrm{~min}$. The liver was immediately dissected out and homogenized in $0.3 \mathrm{M}$ sucrose $(5 \mathrm{ml} / \mathrm{g}$ of tissue) using a Waring blender and centrifuged $115,000 \times \mathrm{g}$ for $25 \mathrm{~min})$. The supernatant was decanted and centrifuged at $100,000 \times \mathrm{g}$ for $90 \mathrm{~min}$ to yield a microsomal membrane pellet that was washed by resuspension of the pellet in $25 \mathrm{mM}$ Tris- $\mathrm{HCl}, 10 \mathrm{mM} \mathrm{MgCl} 2$ buffer $(\mathrm{pH} 7.4)$ (Tris buffer) and centrifuged again under the same conditions. The pellet was then resuspended in the same buffer, and membrane protein was measured by the Bio-Rad assay. Finally, the membranes $(1 \mathrm{mg}$ protein $/ \mathrm{ml})$ were stored frozen at $-20{ }^{\circ} \mathrm{C}$ until use.

Binding studies. - Membranes were gently thawed and homogenized (Dounce) three times. They were centrifuged $(100,000 \times \mathrm{g}$ for $90 \mathrm{~min})$ where specified, in which case, the supernatant was kept for binding studies and the pellet was resuspended in the same volume of Tris buffer. Membrane samples $(100 \mu \mathrm{g}$ of protein) or supernatants $\left(1-2 \mu \mathrm{g}\right.$ of protein) were incubated overnight at $4{ }^{\circ} \mathrm{C}$ with [ $\left.{ }^{125} \mathrm{I}\right]$-labelled hormones $(20,000 \mathrm{cpm}$ for IGF-I and IGF-II, 30,000 cpm for insulin) in a final volume of $0.5 \mathrm{ml}$ Tris buffer containing $0.1 \%$ pure BSA. Nonspecific binding was determined by adding an excess of semi-purified IGFs $(20 \mu \mathrm{g})$ for both IGF-I and IGF-II binding studies and an excess of $10 \mu \mathrm{g}$ of insulin for insulin binding studies. Bound and free hormones were separated by adding $3 \mathrm{ml}$ ice-cold Tris buffer and centrifugating at 4,000 rpm for $30 \mathrm{~min}$. Soluble binding activity was measured by adding $1 \mathrm{ml} 0.125 \%$ rabbit gammaglobulin, followed by $1 \mathrm{ml} 25 \%$ polyethyleneglycol (PEG 8000), both in Tris buffer, followed by thorough mixing and standing for $15 \mathrm{~min}$ at $4{ }^{\circ} \mathrm{C}$ before centrifugation as above. The tubes were then decanted and the radioactivity counted in a gammacounter (LKB).

\section{Results.}

When bound and free hormones were separated by dilution and centrifugation of the membranes, the binding of IGF-II to liver microsomes (fig. 1, row A) was significantly less in Hypox than in normal rats $(15 \pm 2$ vs $26 \pm 1 \%$, $\mathrm{p}<0.001)$ while there was no change in the binding of IGF-I $13.5 \pm 1 \mathrm{vs}$ $3 \pm 1 \%$ ). When separation was achieved using PEG (fig. 1, row B), both IGF-II and IGF-I binding became significantly higher in Hypox than in normal rats (46 \pm 1.5 vs $31 \pm 1$ and $14.5 \pm 2$ vs $6 \pm 1 \%$ respectively, $p<0.001$ ).

No difference in the binding of either IGF-II or IGF-I was observed between Hypox and normal rat liver microsomes $(33 \pm 1$ vs $32 \pm 1$ and $2 \pm 0.5$ vs $3 \pm 1 \%$ respectively) which were prewashed prior to binding assay (fig. 1 , row $\mathrm{C}$ ). In the corresponding supernatants (fig. 1, row D), the binding of both IGF-II and IGF-I was significantly higher in Hypox than in normals (17 \pm 2 vs $6 \pm 0.5$ and $14 \pm 1$ vs $2.5 \pm 0.5 \%$, respectively ; $p<0.001$ ) 
In contrast, there was no difference in the binding of insulin to liver microsomes of Hypox and normal rats whatever the separation technique nor with prewashing of the membranes (fig. 1, rows $A, B, C$ ). In all cases insulin binding varied between 9 and $13 \%$. In the supernatants corresponding to microsomal washings, insulin binding was less than $1 \%$ in both Hypox and normals (fig. 1 row D).

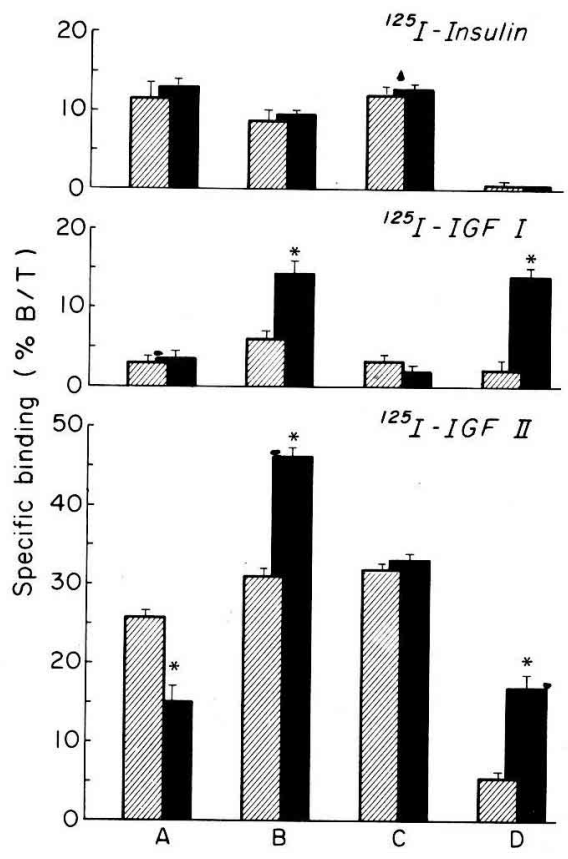

FIG. 1. - [125|]-IGF-I, [125|]-IGF-II and [125|]-insulin specific binding to liver microsomal fractions in (1) normal and (Q) Hypox rat.

Rows $A$ and $B$ : Binding measured following (A) usual separation method of free and bound hormones by adding $3 \mathrm{ml}$ cold Tris buffer and centrifugation ; (B) precipitation of any bound hormone in PEG. Rows $C$ and $D$ : Microsomes were prewashed before binding studies (see Materials and Methods), then hormone binding was assayed separately on (C) the microsomal pellet and (D) corresponding washings (supernatant). Mean \pm SEM $(n=6)$.

${ }^{*}$ ) Significantly different from normal controls $(p<0.001)$.

The inhibition of [125]]-IGF-II binding to liver microsomes of normal rats was progressive over a range of $0.5-500 \mathrm{ng} / \mathrm{ml}\left(I C_{50}=6 \mathrm{ng} / \mathrm{mI}\right)$ of unlabelled IGF-II (fig. 2). With microsomes from Hypox rats, the binding of [125I]-IGF-II was lower than in normals (13 vs $22 \%$ ) and paradoxically increased in the presence of 0.5 $5 \mathrm{ng} / \mathrm{ml}$ of unlabelled IGF-II before decreasing as higher concentrations of IGF-II were added $(10-500 \mathrm{ng} / \mathrm{ml})$.

In the soluble fraction of the binding medium of normal rat microsomes, there was a measurable specific binding of [ $\left.{ }^{125} \mid\right]-\mid G F-I I$ which increased from 0.5 to $2.5 \%$ in presence of $0.5-20 \mathrm{ng} / \mathrm{ml}$ unlabelled IGF-II (fig. 2). The percentage of [125I]-IGF-II specifically bound to the corresponding fraction of Hypox rat microsomes was higher than that of normals $(7.5 \mathrm{vs} 0.5 \%)$ and binding 
decreased in a dose-dependent manner in presence of unlabelled IGF-II 10.5 $500 \mathrm{ng} / \mathrm{ml} ; \mathrm{IC}_{50}=3.5 \mathrm{ng} / \mathrm{ml}$ ).

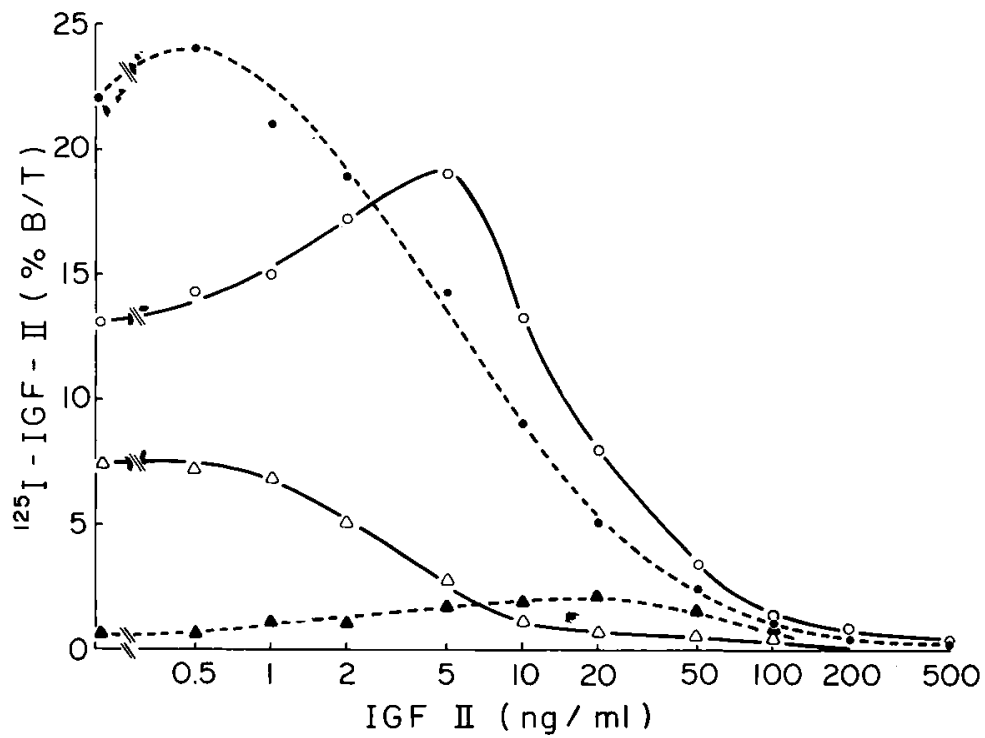

FIG. 2. - Inhibition dose-response curves of /125//-/GF-// binding to liver microsomes and so/uble binding moiety in normal and Hypox rats. At the end of incubation, the tubes were centrifuged $\left(4,000 \mathrm{rpm}, 30 \mathrm{~min} .4^{\circ} \mathrm{C}\right)$. Then $400 \mu \mathrm{l}$ of supernatant (binding supernatant) were transferred into fresh tubes. $(0,0)$ The pellets were resuspended in $3 \mathrm{ml}$ Tris buffer and bound and free hormones were separated by centrifugation. $(\Delta, \Delta)$ Bound IGF in the binding supernatants was separated from free hormone using precipitation by PEG.

Membrane pellet : Control -

Supernatant : Control $\mathbf{\Delta}-\cdot-\cdot-\cdot-\cdot \mathbf{\Delta} ;$ Hypox $\Delta-\Delta$.

\section{Discussion.}

Our experiments indicate that there is no effect of hypophysectomy on the binding of IGF-I and IGF-II to washed rat liver microsomes. Since the predominant form of the IGF receptor in this species is type-II (Daughaday et al., 1981a), we can infer that the regulation of hepatic type-II IGF receptors is not pituitary dependent. This finding parallels the observation that plasma IGF-II levels are less well related to plasma GH levels than IGF-I (Zapf et al., 1981 ; Daughaday et al., 1981b ; Roberts et al., 1986).

The reduced binding of IGF-II to unwashed hepatic microsomes from Hypox rats was caused by the presence of soluble binding proteins which were readily dissociated from the membranes to compete with IGF receptors for binding to the ligand. This was also observed in normal rats but to a much lesser extent. In the latter animals, the majority of the soluble moiety may have been bound to endogenous IGFs:

The importance of the interference of soluble binding proteins in the binding of IGF-II to membrane receptors was well demonstrated by inhibition dose- 
response studies. In Hypox rats, the presence of the binding moiety in microsomal fractions induced a paradoxical increase of IGF-II binding to membrane receptors at low doses of unlabelled ligand. The binding moiety probably mediated this effect since [ $\left.{ }^{125} \mathrm{I}\right]-\mathrm{IGF}-\mathrm{Il}$ binding to membrane receptors increased when the binding to soluble binding sites was decreasing, and began to decrease on membranes when saturation of the soluble sites was almost complete. Similar paradoxical increases of labelled-IGF binding at low doses of unlabelled hormone have been previously observed in studies of IGF-I binding to cultured human fibroblasts (De Vroede et al., 1986 ; Clemmons et al., 1986) and IGF-II binding to erythroleukemia cells (Blanchard et al., 1987). In the former studies, the phenomenon was attributed to the release of membrane-associated IGF binding proteins into the medium though it was not demonstrated in the latter study.

Several differences were observed in the binding moieties released from liver microsomes of either Hypox or normal rats. In normal rats, IGF binding to soluble material was low and had little effect on IGF binding to microsomes. We recently reported that IGF-II has equal affinity for the soluble moiety and the membrane receptor sites (Barenton et al., 1986). Conversely in Hypox rats, IGF binding to the soluble moiety was high and interfered with the binding of IGFs to microsomes. In addition, the affinity of IGF-II for the soluble binding moiety was higher than for membrane receptor sites. This was recently confirmed by Scatchard analyses of separate binding assays with microsomal membranes and the corresponding soluble material (Barenton et al., 1986). Changes in the affinity of plasma binding proteins have been previously reported in hypopituitary children (Hintz et al., 1981). Thus, it is possible that the structure of the molecule(s) released from Hypox rat liver is modified or that there are different binding moieties in Hypox and normal animals.

The material released from liver microsomes had the characteristics of IGF binding proteins since it bound IGF-II with high affinity and did not bind insulin. It is not yet possible to state whether or not the binding moiety is related to plasma IGF binding proteins. Grizzard et al. (1984) reported that membrane-associated IGF binding proteins released from placental membranes represented a contamination by plasma and/or amniotic fluid binding proteins. This is unlikely in our experiments because blood was removed from the liver by prior perfusion. In addition there should be less contamination in Hypox rats since plasma IGF binding proteins are depressed in these animals (Moses et al., 1976). In contrast, binding to the soluble moiety increased in Hypox animals.

The heterogeneity of IGF binding proteins is now well documented (Rechler et al., 1980 ; Furlanetto, 1980 ; Morris and Schalch, 1982). Some binding protein species are GH-dependent (Kaufmann et al.,1978; Moses et al., 1979) while others are not (Hintz et al., 1981 ; Binoux et al., 1982b). As observed in the rat plasma (D'Ercole and Wilkins, 1984), it is possible that the binding moiety harvested from normal rat liver is predominantly related to $\mathrm{GH}$-dependent binding proteins and that most obtained from Hypox animals are related to non-GHdependent binding proteins. Differences have also been observed according to the respective affinities of the binding proteins for each IGF (Binoux et al., 
1982a). Such information about membrane-released moieties is not yet available.

We conclude from these experiments that hypophysectomy has no effect on IGF binding to rat hepatic membrane receptors. However, the liver, and maybe other tissues, release binding moieties which interfere in the binding of IGF to their membrane receptor sites. We speculate that these molecules are involved in the modulation of IGF biological effects at the cell surface.

$12^{e}$ Réunion du groupe Développement I.N.R.A., Montpellier, 28-30 mai 1986.

Acknowledgements. - The present study was partly supported by I.N.R.A., FranceQuebec exchange program (BB) and MRC grants MT4403 (HJG) and MT4182 (BIP).

Résumé. Liaison des facteurs de croissance /GF-I et /GF-l/ aux microsomes hépatiques de rats hypophysectomisés: altération par un composant soluble.

Au cours de cette étude, nous avons comparé la liaison de IGF-I et IGF-II aux microsomes hépatiques chez des rats normaux et hypophysectomisés (Hypox). Nous avons trouvé que la lidison de [ ${ }^{125}$ I]-IGF-II est plus faible chez le rat Hypox que chez le rat normal $(15 \pm 2$ vs $26 \pm 1 \%, p<0,001)$ lorsqu'elle est mesurée par centrifugation des membranes, mais elle devient plus élevée $(46 \pm 1,5$ vs $31 \pm 1 \%, p<0,001)$ lorsque les fractions libre et liée de l'hormone sont séparées par précipitation au polyéthylèneglycol (PEG). Ceci est dû à la présence de sites de liaison solubles qui se dissocient des membranes et entrent en compétition avec le récepteur. Quand la fraction liante soluble est séparée de la fraction microsomiale par un processus de lavage, la liaison de [ ${ }^{125}$ I]-IGF-II sur les microsomes est identique chez les rats Hypox et normaux. En revanche, cette liaison est beaucoup plus élevée dans les résidus de lavage des microsomes (contenant la fraction liante soluble) des rats Hypox que dans celle des rats normaux $(17 \pm 2$ vs $6 \pm 0,5 \%, p<0,001)$. La liaison de [125I]IGF-I est inférieure à celle de [ $\left.{ }^{125} \mid\right]-I G F-1 \mid$ mais varie dans les mêmes proportions. Au contraire, la liaison de [ $\left.{ }^{125} \mathrm{l}\right]$-insuline n'est influencée ni par l'emploi du PEG pour la précipitation, ni par le prélavage des membranes et ne diffère jamais entre les groupes d'animaux.

Les courbes d'inhibition compétitive mettent en évidence une augmentation paradoxale de la liaison de [125|]-|GF-II sur les microsomes de rat Hypox dans une gamme de $0,5-5 \mathrm{ng} / \mathrm{ml}$ d'IGF-II froid. Cette liaison est progressivement inhibée par IGF-\|l dans une gamme de $0,5-500 \mathrm{ng} / \mathrm{ml}$ chez le rat normal. L'inhibition de la liaison de [ ${ }^{125} \mid \mathrm{I}-\mathrm{IGF}-\mathrm{II}$ sur la fraction soluble, mesurée par précipitation au PEG, est dose-dépendante. L'IC $C_{50}$ correspondant à la fraction liante soluble chez les Hypox $(3,5 \mathrm{ng} / \mathrm{ml})$ est presque la moitié de la valeur trouvée pour les récepteurs membranaires $(6 \mathrm{ng} / \mathrm{ml})$.

Nous concluons que I'hypophysectomie est sans effet sur la liaison des IGFs aux récepteurs hépatiques de rat. Toutefois, une fraction liante soluble faiblement associée aux membranes réduit la capacité de liaison des IGFs à leurs récepteurs membranaires chez le rat Hypox.

\section{References}

BARENTON B., PATEL B. A., GUYDA H. J., POSNER B. I., 1986. Characterization of tissue IGF-II binding proteins in the rat liver. 68th ann. Meet. Endocr. Soc., Anaheim (CA) June 25-27. Abst. No 211.

BINOUX M., HARDOUIN S., ! LASSARRE C., HOSSENLOPP P., 1982a. Evidence for production by the liver of two IG binding proteins with similar molecular weight but different affinities for IGF-I and IGF-II. Their relations with serum and cerebrospinal fluid IGF binding proteins. J. clin. Endocrinol. Metab., 55, 600-602. 
BINOUX M., LASSARRE C., HARDOUIN N., 1982b. Somatomedin production by rat liver in organ culture. III. Studies on the release of insulin-like growth factor and its carrier protein measured by radioligand assays. Effects of growth hormone, insulin and cortisol. Acta endocrinol., 99, 422-430.

BLANCHARD M. M., BARENTON B., SULLIVAN A., PATEL B. A., GUYDA H. J., POSNER B. I., 1987. Characterization of the insulin-like growth factor (IGF) receptors in K562 erythroleukemia cells : Evidence for a biological function for type II IGF receptor (Submitted).

CLEMMONS D. R., ELGIN R. G., HAN V. K. M., CASELLA S. L., D'ERCOLE A. J., VAN WYK J. J., 1986. Cultured fibroblast monolayers secrete a protein that alters the cellular binding of somatomedin-C/insulin-like growth factor I. J. clin. Invest., 77, 1548-1556.

COHEN K. L., NISSLEY S. P., 1976. The serum half-life of somatomedin activity: evidence for growth hormone dependence. Acta endocrinol., 83, 243-258.

DAUGHADAY W. H., MARIZ I. K., TRIVEDI B., 1981a. A preferencial binding site for insulin-like growth factor II in human and rat placental membranes. J. clin. Endocrinol. Metab., 53, 282288.

DAUGHADAY W. H., TRIVEDI B., KAPADIA M., 1981b. Measurement of insulin-like growth factor II by a radioreceptor assay in serum of normal individuals, patients with abnormal growth hormone secretion, and patients with tumor-associated hypoglycemia. J. clin. Endocrinol. Metab., 53, 289-294.

D'ERCOLE A. J., WILKINS J. R., 1984. Affinity labeled somatomedin-C binding proteins in rat sera. Endocrinology, 114, 1141-1144.

DE VROEDE M. A., TSENG L. Y.-H., KATSOYANNIS P. G., NISSLEY S. P., RECHLER M. M., 1986. Modulation of insulin-like growth factor I binding to human fibroblast monolayer cultures by insulin-like growth factor carrier proteins released to the incubation media. J. clin. Invest., 77, 602-613.

DROP S. L. S., VAliQuetTe G., GUYdA H. J., CORVOL M. T., POSNeR B. I., 1979. Partial purification and characterization of a binding protein for insulin-like activity (ILAs) in human amniotic fluid : a possible inhibitor of insulin-like activity. Acta endocrinol, 90, 505-518.

FURLANETTO R. W., 1980. The somatomedin-C binding protein: Evidence for a heterogenous subunit structure. J. clin. Endocrinol. Metab., 51, 12-19.

GRIZZARD J. D., D'ERCOLE A. J., WILKINS J. R., MOATS-STAATS B. M., WILLIAMS R. W., 1984. Affinity labeled somatomedin-C receptors and binding proteins from the human fetus.

J. clin. Endocrinol. Metab., 58, 535-543.

HINTZ R. L., LIU F., ROSENFELD R. G., KEMP S. F., 1981. Plasma somatomedin-binding proteins in hypopituitarism: changes during growth hormone therapy. J. clin. Endocrin. Metab., 53, 100-104.

KASUga M., VAN OBBERGHEN E., NISSLEY S. P., RECHLER M. M., 1981. Demonstration of two subtypes of insulin-like growth factor receptors by affinity cross-linking. J. biol. Chem., 256, 5305-5308.

KAUFMANN U., ZAPF J., FROESCH E. R., 1978. Growth hormone dependence of nonsuppressible insulin-like activity (NSILA) and NSILA-carrier protein in rats. Acta endocrinol., 87, 716-727.

MORRIS D. H., SCHALCH D. S., 1982. Structure of somatomedin binding protein : alkaline $\mathrm{pH}$-induced dissociation of an acid-stable, 60,000 molecular weight complex into smaller components. Endocrinology, 111, 801-805.

MOSES A. C., NISSLEY S. P., COHEN K. L., RECHLER M. M., 1976. Specific binding of a somatomedin-like polypeptide in rat serum depends on growth hormone. Nature, 263, 137-140.

MOSES A. C., NISSLEY S. P., PASSAMANI J., WHITE R. M., RECHLER M. M., 1979. Further characterization of growth hormone-dependent somatomedin-binding proteins in rat serum and demonstration of somatomedin-binding proteins produced by rat liver cells in culture. Endocrinology, 104, 536-546.

NISSLEY S. P., RECHLER M. M., 1985. Insulin-like growth factors : biosynthesis, receptors, and carrier proteins. In Hormonal protein and peptides, Vol. XII. Acad. Press, New York, pp. 127-203.

POSNER B. I., GUYDA H. J., CORVOL M. T., RAPPAPORT R., HARLEY C., GOLDSTEIN S., 
1978. Partial purification, characterization, and assay of a slightly acidic insulin-like peptide (ILAs) from human plasma. J. clin. Endocrinol. Metab., 47, 1240-1250.

RECHLER M. M., ZAPF J., NISSLEY S. P., FROESCH E. R., MOSES A. C., PODSKALNY J. M., SCHILLING E. E., HUMBEL R. E., 1980. Interactions of insulin-like growth factors 1 and II and multiplication-stimulating activity with receptors and serum carrier proteins. Endocrinology, 107, 1451-1459.

ROBERTS Jr C. T., BROWN A. L., GRAHAM D. E., SEELIG S., BERRY S., GABBAY K. H., RECHLER M. M., 1986. Growth hormone regulates the abundance of insulin-like growth factor I RNA in adult rat liver. J. biol. Chem., 261, 10025-10028.

ZAPF J., WALTER H., FROESCH E. R., 1981. Radioimmunological determination of insulin-like growth factors $I$ and $I I$ in normal subjects and in patients with growth disorders and extrapancreatic tumor hypoglycemia. J. clin. Invest., 68, 1321-1330. 